\title{
Comparative study of the relationship between childhood traumas with personality function and pathological traits in patients with borderline personality disorder and non-patient group
}

\author{
Mona Ostad Noroozi ${ }^{1}$, Mehdi Zemestani ${ }^{2}$ \\ 1-M.Sc of Clinical Psychology, Department of Psychology, University of Kurdistan, Sanandaj, Iran (Corresponding \\ Author). $\quad$ E-mail: Mostadnoroozy@gmail.com \\ 2- Associate Professor, Department of Psychology, University of Kurdistan, Sanandaj, Iran.
}

Received: $22 / 10 / 2020$

Accepted: 10/01/2021

\begin{abstract}
Introduction: A review of the background of people with borderline personality disorder shows that most of these people were raised in shaky family environments.

Aim: The aim of this study was to predict the relationship between personality function and pathological traits in patients with borderline personality disorder and normal group through childhood traumas.
\end{abstract}

Method: The present study was a causal-comparative and correlational study. The statistical population consisted of 214 students of the academic year 2018-2019 of Kurdistan University and 25 patients with borderline personality disorder hospitalized from December to February 2018 in Ghods Psychiatric Hospital, by available sampling method. And Childhood Injury Questionnaires (Bernstein and Fink, 1998), the Large-Scale Personality Function Levels (Murray et al., 2011), the Long Version of the Personality Checklist for the Fifth Edition of the Diagnostic and Statistical Manual of Psychiatric Disorders (American Psychiatric Association, 2013) and the Personality Disorders Questionnaire (First et al., 1997) responded. Data analysis was performed using Pearson correlation test and logistic regression analysis.

Results: There was a direct and significant relationship between the scores of borderline personality disorder and personality function at the level of $(\mathrm{P}<0.000)$ and childhood trauma at the level of $(\mathrm{P}<0.000)$. The findings of the present study using logistic regression showed that personality dysfunction and childhood traumas at the $(\mathrm{P}<0.000)$ level are able to distinguish between 23 and $48 \%$ of the group with borderline personality disorder from the non-clinical group.

Conclusion: According to the results of borderline personality disorder, personality trauma can be predicted through childhood traumatic experiences and dysfunction. Clinicians are advised to consider the role of childhood trauma in dealing with borderline patients.

Keywords: Borderline personality disorder, Child abuse, DSM-V, Student

How to cite this article : Ostad Noroozi M, Zemestani M. Comparative study of the relationship between childhood traumas with personality function and pathological traits in patients with borderline personality disorder and non-patient group. Shenakht Journal of Psychology and Psychiatry. 2021; 7 (6): 85-99 .URL: http://shenakht.muk.ac.ir/article-1-982-en.pdf

Copyright ( 2018 the Author (s). Published by Kurdistan University of Medical Sciences. This is an open access article distributed under the terms of the Creative Commons Attribution-Non Commercial License 4.0 (CCBY-NC), where it is permissible to download, share, remix, transform, and buildup the work provided it is properly cited. The work cannot be used commercially without permission from the journal. 


\section{بررسى مقايسهاى ارتباط بين تروماهاى دوران كودكى با كاركرد شخصيت و صفات مرضى در

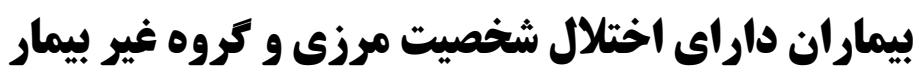

\section{منا استادنوروزى'، مهدى زمستانى}

ا. كارشناس ارشد روانشناسى بالينى، گروه روانشناسى بالينى، دانشخاه كردستان، سنندج، ايران (مولف مسئول). ايميل: Mostadnoroozy @ gmail.com

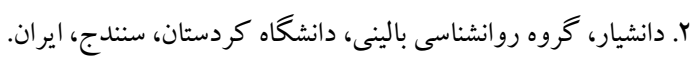

مقدمه: بررسى ييشينه افراد داراى اختلال شخصيت مرزى نشان مىدهد كه اغلب اين افراد در محيطهاى متزلزل خانوادكى يرورش يافتهاند.

هدف: بزوهش حاضر با هدف بيشبينى رابطهى كار كرد شخصيت و صفات مرضى در بيماران داراى اختلال شخصيت مرزى و گروه نرمال از طريق تروماهاى دوران كودكى انجام شد.

روش: يزوهش حاضر از نوع على - مقايسهاى و همبستكى بود. جامعه آمارى را IIIF نفر از دانشجويان سال تحصيلى

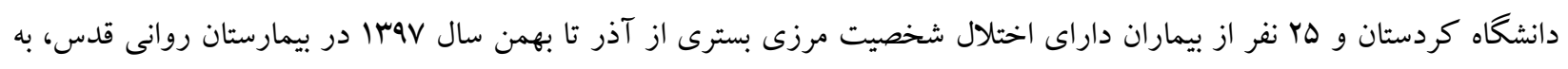

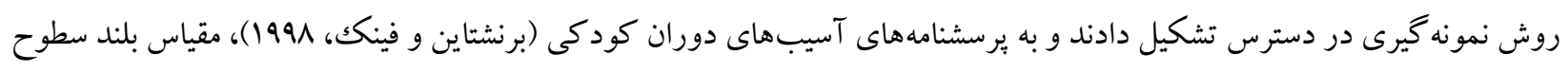

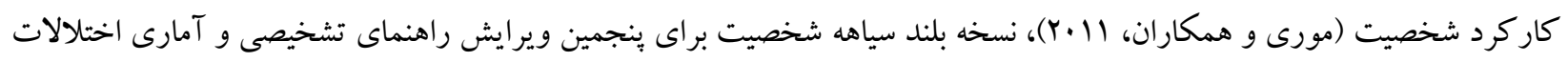

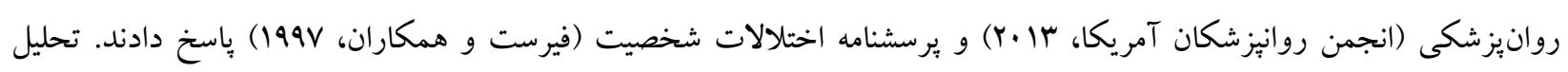

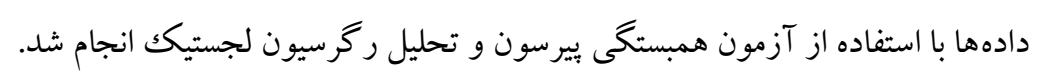

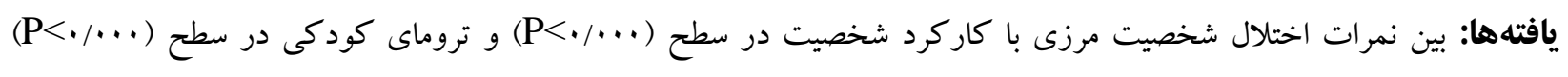

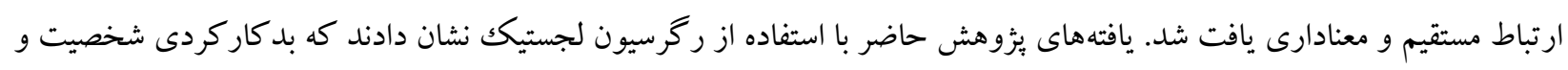

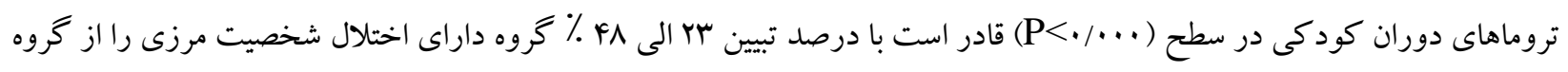
غير بالينى تفكيك نمايد.

نتيجه كيرى: با توجه به نتايج اختلال شخصيت مرزى از طريق تجارب تروماتيك دوران كودكى و بدكاركردى شخصيت قابل

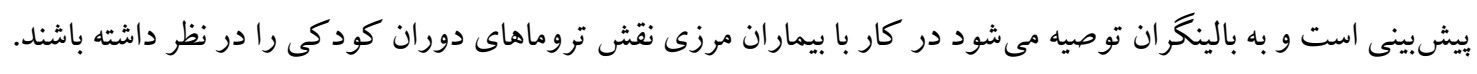
كليدوازهها: اختلال شخصيت مرزى، سوء استفاده از كودك،، ينجمين ويرايش راهنماى تشخيصى و آمارى اختلالات روانيزشكى، دانشجويان 
و جالشهاى دوران كودكى و كز كارى نسبتاً ظريف

مقدمه

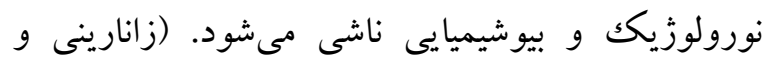
اختلال شخصيت مرزى' كه حدود ب-1\% از جمعيت

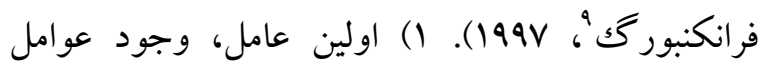
عمومى را تحت تأثير قرار مىدهد، اختلال شديد روانى تروماتيك در خانواده است كه در قالب كستردهاى

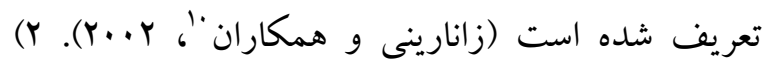
دومين فاكتور وجود خلق و خوى آسيب يذير در اين افراد است؛ اين افراد احساسات غير قابل تحمل از خشم، غم و شرم را به تلاشى بىوقفه براى جلب توجه ديخران به عظمت درد هيجانىاى كه احساس مى كنند، تبديل مى كنند. ب)سومين عامل ضرورى براى توسعه اختلال شخصيت مرزى يكك رويداد يا مجموعهاى از وقايع (تجربيات نرمال يا آسيبهاى طبيعى و اتفاقى) است (زانارينى وفرانكبورگك ، 1994). در راستاى اين نظريات يخوهش هاى زيادى صورت كرفته است كه در نتيجه آن ها اختلال شخصيت مرزى از يكك محيط زندكى نابيايدار و غير قابل اطمينان دوران كودكى ايجاد مىشود و به طور خاص توسط سوء رفتار عاطفى و عواطف منفى مشخص

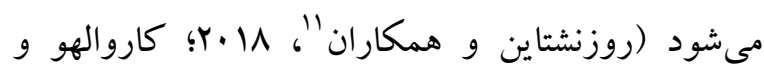
همكاران"' اسـتفاده و غفلـت از كـودكك در اشـكال مختلــف اتفــاق مىافتد؛ كه شامل سـوء اسـتفاده جنسـى، جسمى (جراحت عمدى كودكى (انجمن روان بزشكان

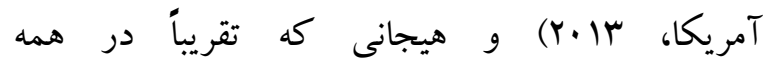
بلدرفتارىهايى كه با كودك مىشود، به جشم مىخورد

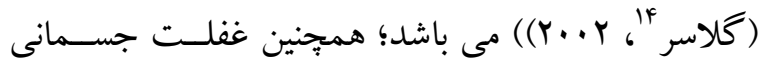
است كه از مشخصههاى بارز آن مىتوان به بىثباتى

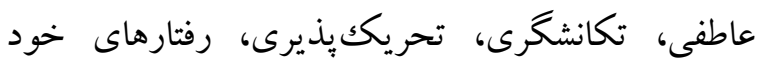
جرحى، روابط بين فردى نايايدار و نارسايىهاى معنىدار در توانايى تنظيم هيجان اشاره كرد (انجمن روان بزشكان

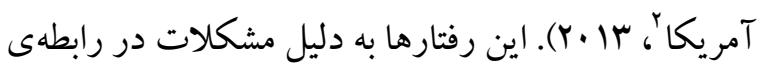
والد - فرزندى و سبك تربيت والدين در اوايل كودكى

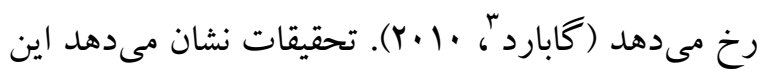
افراد معمولاً دجار غفلت، بى توجهى و يا سوء استفاده كلامى بودهاند و يا به صورت نامناسب آموزش ديدهاند. گاهى سابقهى طلاق، مرگك زودرس والدين و تروماهايى (سوء استفاده جسمى و جنسى) در تاريخجهى دوران كودكى مبتلايان به اين اختلال ديده مىشود (هولم و

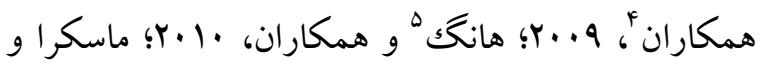

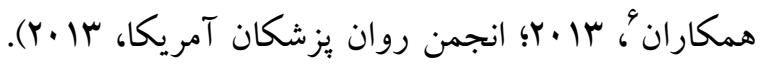
تشخيص زودهنگام اين بيمارى مىتواند سبب كمكك به روان بهبود و تغيير دورهى بيمارى و كم كردن هزينهاى كز افى كه خود اين افراد و خانو اده هايشان بايد بيردازند،

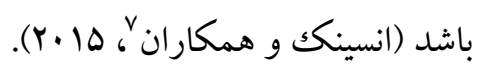

مدلى كه تا حد بسيار زيادى توانسته است به تبيين علل اختلال شخصيت مرزى ببردازد، مدل زانارينى ^ (1994) است . طبق اين مدل شكل گيرى اختلال شخصيت مرزى، از تركيب يِيجيدهى سه مؤلفهى مزاج فرد، تروماها (عدم تأمين كافى نيازهاى فيزيكى كودكك (جلن، مكلور

\footnotetext{
9 - Zanarini \& Frankenburg

${ }^{10}$ - Znarini, et al.

11- Rosenstein, et al.

12 - Carvalho, et al.

13- Salwen, et al.

14 - Glaser
}

\footnotetext{
1. Borderline Personality Disorder

2- APA

3. Gabbard

4- Holm, et al.

5- Haung, et al.

6 - Mosquera, et al.

7. Ensink, et al.

8 - Zanarini
} 


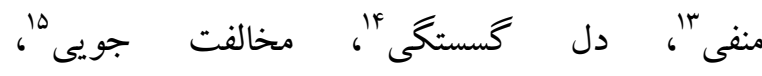

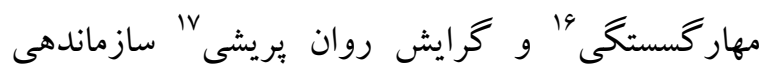

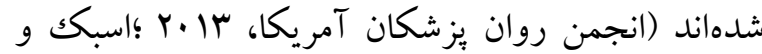

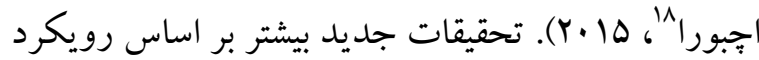
ابعادى موجود در بخش سوم ينجمين ويرايش راهنماى تشخيصى و آمارى اختلالات روان بزشكى و ارتباط آنها با تروماهاى دوران كودكى انجام مىشود (كروكر

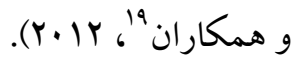
بنا بر آنجه كفته شد در تاريخجٍه دوران كودكى بخش

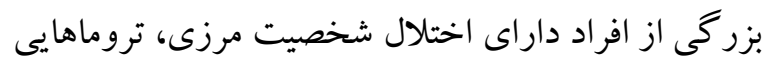
اعم از انواع سوء استفاده و غفلت به جشم مى خورد. على رغم وجود اين گزارشهاى متعدد در مورد ارتباط تاريخجهى تروماهاى دوران كودكى با موارد بالينى اختلال شخصيت مرزى ، مطالعات كمى در همين حوزه در جمعيت غير بالينى انجام شده است. در حالى كه بد رفتارى و غفلت با كودكان در جامعه از آمار بالايى برخوردار است و اثرات جبران نايذيرى بر سلامت روان افراد دارد، يس در يُزوهش حاضر سعى بر آن بوده كه هر دو گروه بالينى و غير بالينى در نمونه گنجانده شود. با توجه به مشكلات تشخيصى اين اختلال و بحث هاى مبنى بر مدل جايخزين در فصل سوم ينجمين ويرايش راهنماى تشخيصى و آمارى اختلالات روان بزشكى و جاى خالى يثزوهشهايى درمورد بدكاركردى و صفات مرضى شخصيت در جمعيت بالينى و غير بالينى در مورد اختلال شخصيت مرزى، ئزوش حاضر قصد دارد بررسى مقايسهاى در مورد ارتباط بين تروماهاى دوران كودكى

13 - Negative Affectivity

${ }^{14}$ - Detachment

15- Antagonism

${ }^{16}$ - Disinhabition

${ }^{17}$ - Psychoticism

${ }^{18}$ - Esbec \& Echeburúa

${ }^{19}$ - Krueger, et al.
و تيلور '، (Y...)، غقلـت هيجانسى (بى توجهى آشكار يا يا برآورده نكردن نيازهاى عاطفى كودكك(گلاسر، Y...Y) و غفلت آموزشى (مجاز دانستن مدرسه گريزى

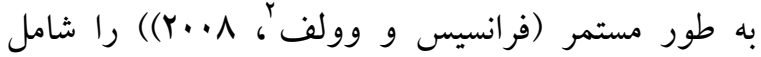

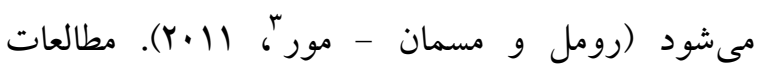
جديدتر نشان مىدهند كه بدرفتارى عاطفى/ هيجانى (يعنى، حملههاى كلامى به احساس خود، احساس

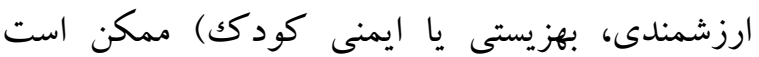
بيشترين ارتباط را در ميان انواع بدرفتارى با افراد داراى

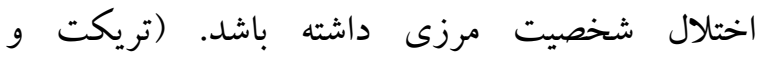

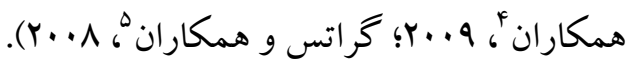
براى ارزيابى اختلالات شخصيت در بخش ضميمهى بنجمين ويرايش راهنماى تشخيصى و آمارى اختلالات روان بزشكى " رويكردهاى تقليل گرايانه و ابعادى نيز معرفى شدهاند. سياهلى شخصيت براى ينجمين ويرايش

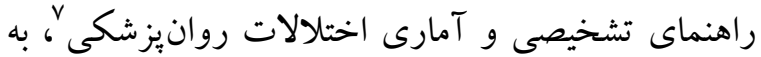
منظور ارزيابى ابعادى شخصيت و اختلالات و مقياس سطوح كاركرد شخصيت` به منظور متمايز ساختن بنج سطح اختلال (عدم اختلال تا شديد) در نظر كرفته شده است. (انجمن روانيزشكان آمريكا، سا •Y). سطح كاركرد شخصيت (ملاكك A)، به معناى آشفتخى در كار كردهاى

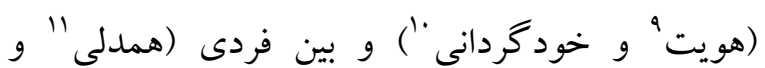
صميميت ") مى باشد، صفات شخصيتى مرضى بيمار گون

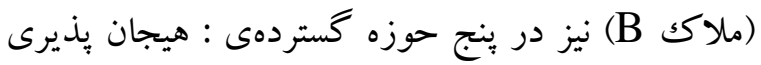

\footnotetext{
'- Jellen, McCarroll \& Thayer

2 - Francis \& Wolfe

3 - Roemmele \& Messman-Moore

4- Trickett, et al.

5 - Gratz, et al.

6 - DSM-5= Diagnostic and Statistical Manual of Mental Disorde

7 - PID-5=Personality Inventory for DSM-5

${ }^{8}$ - LPFS=Level of Personality Functioning Scale

9 - Identity

${ }^{10}$ - Selfdirection

11- Empathy

12- Intimacy
} 
سال، اعلام رضايت، تشخيص اختلال شخصيت مرزى و بسترى بودن در بيمارستان روان يزشكى. ملاككهاى خروج نيز عبارت بودند از: علائم سايكوتيكك يا مانيا، بيمارىهاى يزشكى، مصرف دارو، سوء مصرف مواد. تجزيه و تحليل دادهها با آزمون آمارى همبستكى بيرسون براى بررسى ارتباط بين متغيرهاى ئزوهش و تحليل

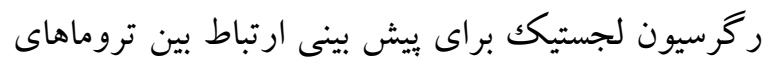

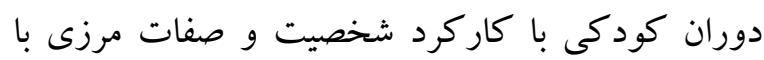
استفاده از نرم افزار SpSS نسخهى MF مورد تجزيه و تحليل قرار گرفت.

ابزار ابزارهاى بزووهش به تفصيل عبارت اند از:

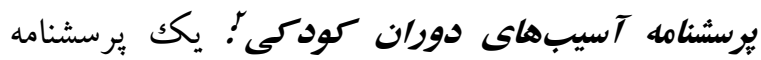
خودگزارشى كه توسط برنشتاين و فينكى " (1991) به ليه صورت F M سؤ الى در ه حيطهى سوء استفادهى عاطفى، فيزيكى، جنسى و غفلت در دو حيطهى عاطفى و فيزيكى براساس طيف ليكرت (از هر زز تا هميشه) ساخته شد. علاوه بر جمع امتيازها براساس نقطهى برش براى هريك از حيطهها نوع متوسط تا شديد تعيين شد كه عبارتاند از: سا و بالاتر براى سوء استفاده هيجانى، ·ا و بالاتر براى سوء استفادهى فيزيكى، ^ براى سوء استفادهى جنسى، ها و بالاتر براى غفلت هيجانى و هم غفلت فيزيكى؛ و به اين ترتيب براساس توصيهى ابداع كنند كان برسشنامه افراد به دو گروه تقسيم مىشوند، كسانى كه نمرهى آن ها در محدودهى متوسط تا شديد قرار داشت و داراى سابقهى سوء استفادهى دوران كودكى و نمرهى كمتر از آن بدون سابقه در نظر كرفته شده است

${ }^{2}$ - $\mathrm{CTQ}=$ Childhood Trauma Questionnaire

${ }^{3}$ - Bernstein \& Fink
با كاركرد شخصيت و صفات مرزى در بيماران داراى اختلال شخصيت مرزى و گرووه غير بيمار انجام دهد.

\section{روش}

روش شناسى بزوهش حاضر كمى بود كه در قالب روش على- مقايسهاى انجام كرفت. جامعه يُزوهش حاضر شامل دو گروه بود. بخش اول گرووه بالينى بودند كه، توسط روان يزشك متخصص يا روانشناس بالينى تشخيص اختلال شخصيت مرزى را دريافت كردند و بسترى بودند. براى اين گروه جامعه در دسترس شامل

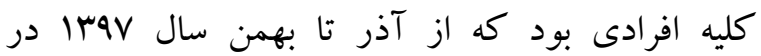
بيمارستان قدس سنتدج بسترى بودند. گروه غير بالينى نيز شامل كليه دانشجويانى است كه در سال تحصيلى Vهr در دانشخاه كردستان مشغول به تحصيل بودند و براى شركت در اين ئزوهش به صورت نمونه گيرى در دسترس انتخاب شده و در اتاق آزمايشگاه روان شناسى دانشگاه كردستان، يرسشنامهاى آسيبهاى دوران كودكى، مقياس بلند سطوح كاركرد شخصيت، نسخه بلند سياهه شخصيت براى ينجمين ويرايش راهنماى تشخيصى و آمارى اختلالات روان بزشكى و برسشنامه اختلالات شخصيت' با ترتيب تصادفى جهت براسخ دهى در اختيار آنان قرارگرفت. در مورد مسائل اخلاقى يُزوهش به افراد اطمينان داده شد كه گمنامى در تكميل ابزارها لحاظ شده است و رازدارى و محرمانه بودن اطلاعات حفظ شده است. در مجموع qجr نفر شناسايى

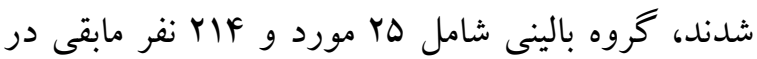
كروه غير بالينى قرار داشتند. در اين بثزوهش ملاككهاى ورود به يُزوهش عبارت بودند از: دامنه سنى 11 تا 49

\footnotetext{
1. SCID-II=Structured Clinical Interview for DSM-IV
} 


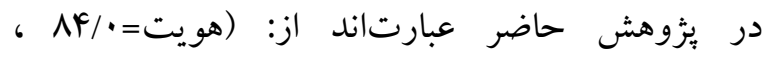

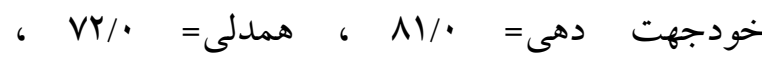

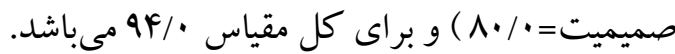
سياهل شخصيت براى بنجمين ويرايش راهنماى تشخيصى

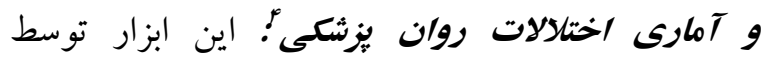

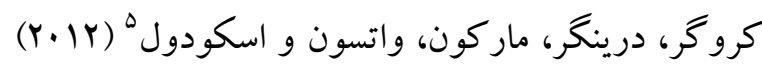
طراحى شده است و داراى دو فرم كوتاه Dr. r و بلند مادهاى و جهار كزينهاى است كه براى سنجش صفات مرضى بيشنهادى پِنجمين ويرايش راهنماى تشخيصى و

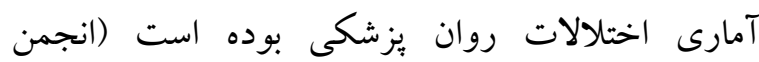
روانيزشكى آمريكا، سا.ب(Y) و مبتنى بر رويكرد ابعادى

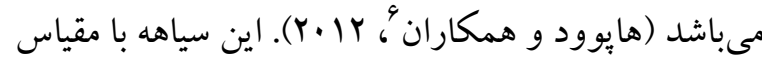
جهار گزينهاى ليكرت از صفر (كاملاً اشتباه يا اغلب

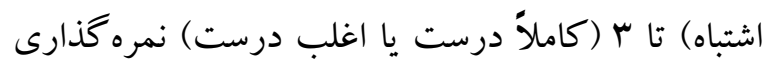
مى شود ساختار عاملى سلسله مراتبى ه حيطه و كا صفت

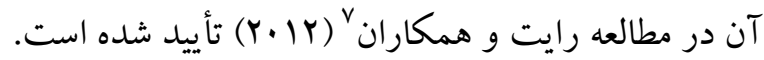

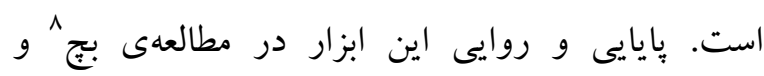

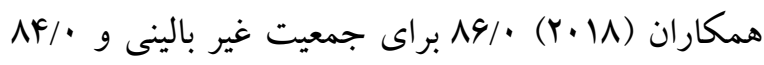
براى جمعيت بالينى گزارش شده است. ساختار عاملى اين ابزار نيز در مطالعه نمونهاى با حجم FDY نفر براى جامعه ايرانى تأييد شده و ضريب آلفاى كرونباخ براى حيطههاى

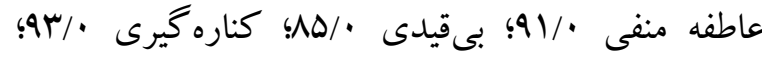

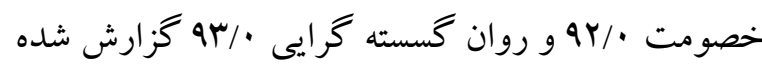

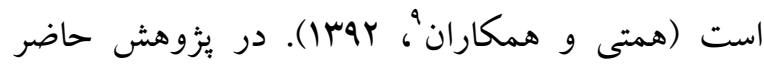
آلفاى كرونباخ براى صفات (عاطفه منفى=•/N ، دل دل

4- PID-5=Personality Inventory for DSM-5

5 - Krueger, Derringer, Markon, Watson \& Skodol

6 - Hopwood, et al.

7. Wrigt, et al.

${ }^{8}$ - Bach

9- Hemmati, et al.
(برنشتاين و فينك، 1991؛ وينگغيلد و همكاران'، · (Y). بايايى آن به دو روش آزمون - بازآزمون و آلفاى

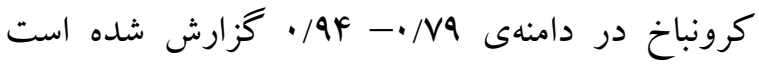

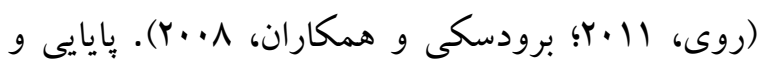
روايى اين برسشنامه توسط ابراهيمى و همكاران (1اسوا) آلفاى كرونباخ را •/1 تا • •/19 به زبان فارسى به دست آوردهاند و رضايى (هوسا) روايى سازهاى آن را تأييد كرده است. آلفاى كرونباخ در بثوهش حاضر براى سوء

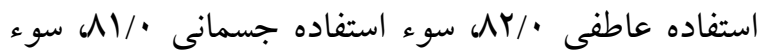

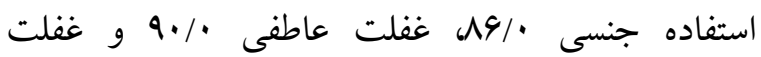
جسمانى اV/ · در يزوهش حاضر گزارش شده است.

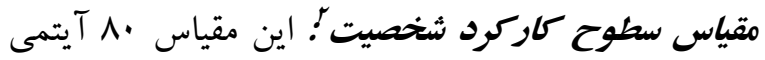
سطوح كاركرد شخصيت توسط بندرّ و همكاران (r.11) مدل جايگزين عنوان شده در ينجمين ويرايش راهنماى تشخيصى و آمارى اختلالات روان يزشكى ساخته شد كه سطوح كاركرد شخصيت را در جهار مؤلفه خود جهت دهى (19 آيتم)، هويت (ا Y T آيتم)، همدلى (T)

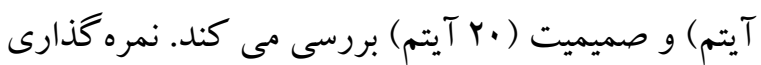

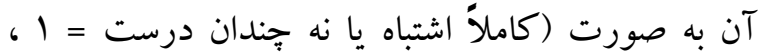

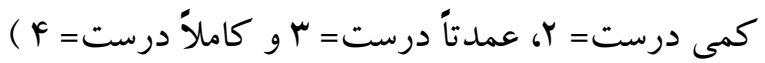

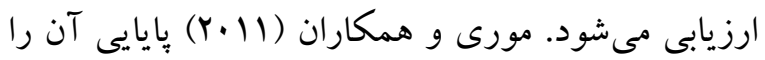
V/VY \$9/. درصد و حساسيت تشخيصى آن را 9/AK درصد كزارش نمودهاند (مورى و همكاران، I|lY). همتى و همكاران

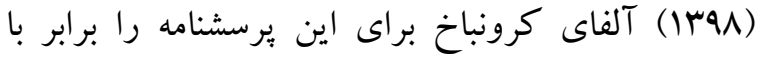

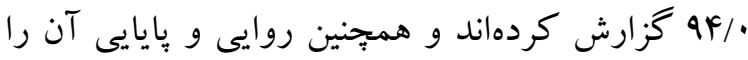
نيز تأييد كردهاند. آلفاى كرونباخ براى ابعاد اين برسشنامه

\footnotetext{
1. Wingenfeld et al.

2- LPFS=Level of Personality Functioning Scale

3 - Bender
} 
نشان داده شد كه بيشترين ميزان تشخيص هماهنك در

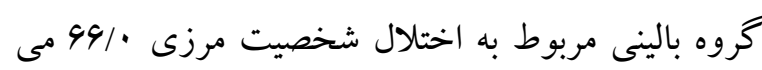

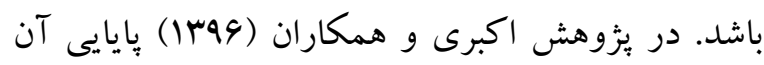

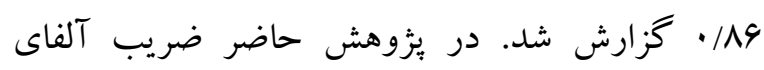

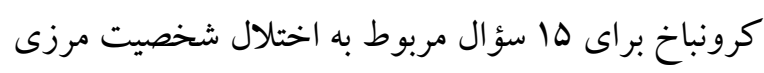

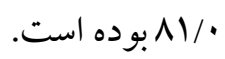

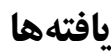

در مطالعه حاضر qجr نفر حضور داشتهاند كه از اين تعداد

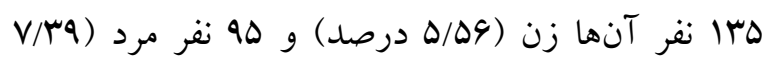
درصد) حضور داشتند و جنسيت ه نفر (T/N درصد) آنها

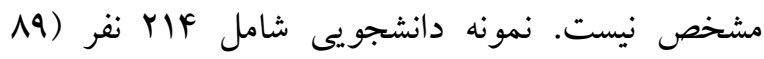

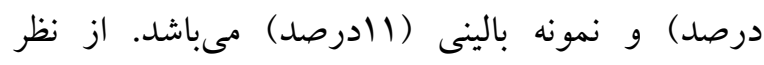
وضعيت تأهل 19 نفر از آنها متأهل و مابقى مجرد بود درند.

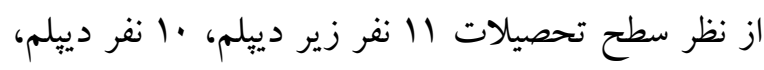
ه.r. نفر كارشناسى و Iل انفر كارشناسى ارشد بودند و تحصيلات مابقى آنها مشخص نيست. در اين مطالعه آمارههاى توصيفى متغيرهاى مورد مطالعه در جداول زير إنائ

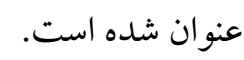

$\Delta V / \cdot=$ كستخى = روانيريش گرايى=//(9) مى باشد. برسشنامه اختلالات شخصيت: اين برسشنامه . r T آيتمى

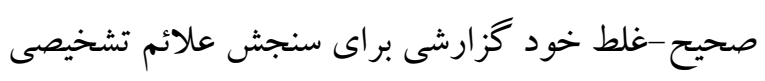
اختلالات شخصيت توسط فيرست و همكاران (199V) براساس مصاحبه ساختارى براى جهارمين ويرايش فيرست

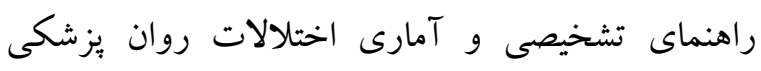

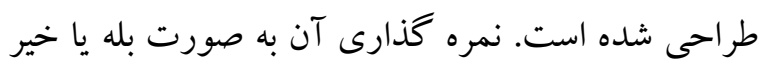

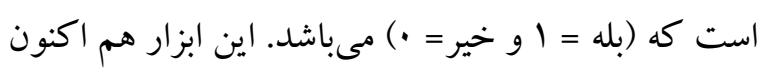

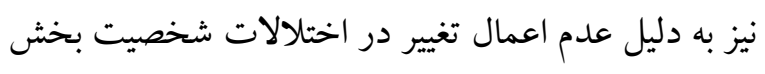

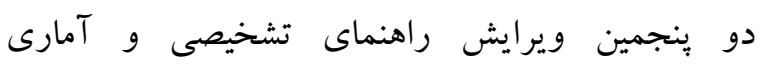

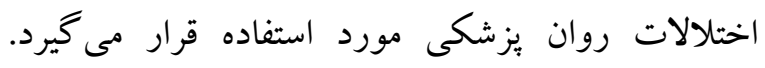
تحقيقات زيادى كاريى اين ابزار رادر استفاده از آن را

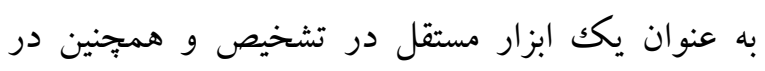

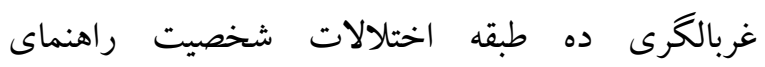

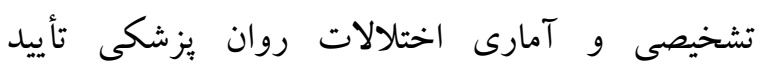
كردهاند. تعداد سؤالات براى تشخيص اختلال شخصيت أشتال

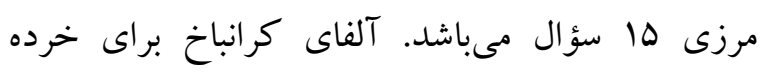

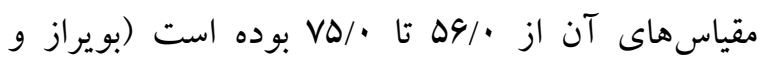

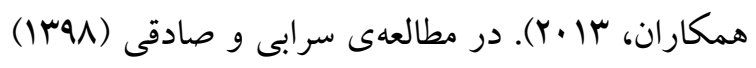

\begin{tabular}{|c|c|c|c|c|}
\hline كشيدتى & 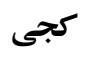 & انحر اف معيار & ميانكين & متغير \\
\hline$-\cdot / M$ & $\cdot / \Upsilon^{9}$ & $\Gamma / \wedge \Delta$ & $9 / 10$ & نمره اختلال شخصيت مرزى \\
\hline $1 / 1$ & $r 4 / 1$ & $9 \pi / r$ & $r / \Lambda$ & نمره آسيب هاى دوران كودكى \\
\hline $\mid+1 / \cdot-$ & $r \Delta /$ & $99 / 91$ & rQ/YA & نمره سطوح كاركرد شخصيت \\
\hline$\Delta q / \cdot-$ & $r \Delta /$ & $r \Delta / f$ & $94 / 1$ & عاطفه منفى \\
\hline$\Delta 9 / \cdot-$ & rq/. & $r \cdot / 4$ & $9 \cdot / V$ & دل كستتى \\
\hline $\mid V / \cdot-$ & $r \cdot /$ & 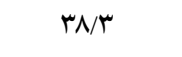 & $\cdot v / V$ & 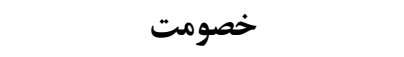 \\
\hline$r \cdot / \cdot-$ & $\mathrm{FV} /$. & $r Y / \varphi$ & ra/ & مهار كستتى \\
\hline $91 / \cdot-$ & $r \cdot /$ & $M / 9$ & $\wedge 1 / 9$ & روان بريش كرايى \\
\hline
\end{tabular}


كودكى، بد كاركردى شخصيت، نمره اختلال شخصيت مرزى و ينج حيطه كلى صفات مرضى شخصيت از آزمون همبستخى ييرسون استفاده شد كه نتايج در جدول شماره r T Tمده است.
درجدول ا ميانگين و انحراف استاندارد نمرات براى همهى اندازه گيرىهاى صورت گرفته ارائه شده است. كجى و كشيد قرار دارد كه قابل يذيرش بوده و حاكى از نرمال بودن دادهها مىباشد. براى بررسى بين تروماهاى دوران

\begin{tabular}{|c|c|c|c|c|c|c|c|}
\hline \multirow[t]{8}{*}{$\checkmark$} & 9 & $\Delta$ & $\varphi$ & $r$ & $r$ & 1 & 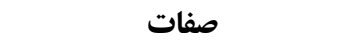 \\
\hline & & & & & & & تروماى دوران كودكى \\
\hline & & & & & & $\cdot /\left.F V\right|^{* * *}$ & بد كاركردى شخصيت \\
\hline & & & & & $\cdot / N Y \varphi^{* * *}$ & $\cdot / 41 \Lambda^{* * *}$ & عاطفه منفى \\
\hline & & & & $\cdot / \Delta r^{* * * *}$ & $\cdot / 9 \cdot 9^{* * * *}$ & $\cdot / K F D^{* * *}$ & دل كستتغى \\
\hline & & & $\cdot / F T V^{* * *}$ & ./V११"** & $\cdot / \Delta \Delta \Delta^{* * *}$ & $\cdot / r Y \Lambda^{* *}$ & خصومت \\
\hline & & $.1910^{* * *}$ & $\cdot / \Delta \lambda r^{* * * *}$ & $\cdot / 4 \& q^{* * *}$ & VYr/ $/ * *$ & $\cdot / 49 r^{* * *}$ & مهار كستتغى \\
\hline & $.199 V^{* * *}$ &.$/ 99 Y^{* * *}$ &.$/ 940^{* * *}$ & $\cdot / r \Delta \cdot * *$ & $\cdot$ D NY *** & $\cdot / \pi 9 V^{* * *}$ & روان يريشى كرايى \\
\hline$\cdot / \Delta \mu q^{* * *}$ & $\cdot / r \cdot r^{* * *}$ & $\cdot / 499^{* * * *}$ & $\cdot / M^{* * * *}$ &.$/ 99 V^{* * *}$ & $\cdot / 9 \Delta 9^{* * *}$ & $\cdot / 499^{* * *}$ & نمره اختلال شخصيت مرزى \\
\hline
\end{tabular}

مستقيم بين متغيرها وجود دارد. همبستخى مرتبه صفر كاركرد شخصيت با نمره اختلال شخصيت مرزى در سطح معنى دارى (·/ (P=... معنىدار است و رابطهى مستقيم بين تمامى متغيرها وجود دارد. همبستكى مرتبه صفر ينج حيطه كلى صفات مرضى شخصيت با نمره اختلال شخصيت مرزى در سطح معنىدارى ( ( P=... معنىدار است و رابطهى مستقيم بين آنها وجود دارد. براى بررسى معنى دارى و برازش مدل ركرسيون لجستيك از آزون هوسمر و لمشو استفاده شده است كه برى نتايج آن در جدول شماره ب گزارش شده است.
همانطور كه در جدول Y مشاهده مىشود همبستگى مرتبه صفر ينج حيطه كلى صفات مرضى شخصيت' با مان

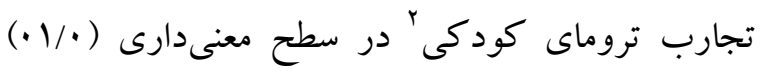
معنى دار است و رابطهى مستقيم بين متغيرها وجود دارد. همبستگى مرتبه صفر كاركرد شخصيت با تجارب

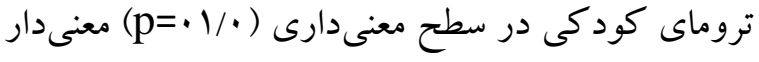
است و رابطهى مستقيم بين تمامى متغيرها وجود دارد. همبستكى هاى مرتبه صفر مولفهاى تجارب تروماى كودكى با نمره اختلال شخصيت مرزى در سطح معنىدارى ( (P=./. معنىدار است و رابطهى مستقيم بين تمامى متغيرها وجود دارد. همبستخى مرتبه صفر بنج حيطه كلى صفات مرضى شخصيت با كاركرد شخصيت در سطح معنى دارى (•/P=(P) معنىدار است و رابطهى 
جدول r شاخصهاى معنى دارى و برازش مدل ركرسيون لجستيك دو جملهاى ويشرونده والد و قدرت تبيين بيشينى

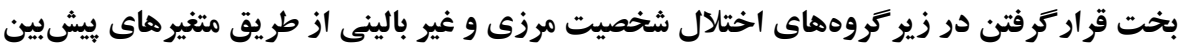

\begin{tabular}{|c|c|c|c|c|c|c|c|c|}
\hline \multicolumn{3}{|c|}{ آزمون هوسمر و لمشو و برازش مدل } & \multicolumn{2}{|c|}{ درصد تبيين واريانس } & \multicolumn{3}{|c|}{ معنى دارى مدل } & \multirow[t]{2}{*}{ مدل } \\
\hline سطح معنادارى & درجه & $\chi^{2}$ & نغلكر كs & سنو كس و & معنادارى سطح & آزادى درجه & $\chi^{2}$ & \\
\hline$\wedge 9 \Delta / \cdot$ & $\wedge$ & $\Delta \Delta / r$ & $\mathrm{r} \mid \Delta / \cdot$ & $\mid \Delta F /$. & $\cdots / \cdot$ & 1 & $M N / r q$ & 1 \\
\hline r/q/. & $\wedge$ & $V M / l$. & 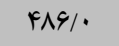 & rTV/. & $\cdots /$ & r & $V Y / G F$ & $r$ \\
\hline
\end{tabular}

همخوان است. تحليل رگرسيون لجستيك براى بيشبينى ارتباط بين تروماهاى دوران كودكى با كار كرد شخصيت و صفات مرزى در جدول F نشان داده شده است.
با توجه به اطلاعات درج شده در جدول م نيكويى

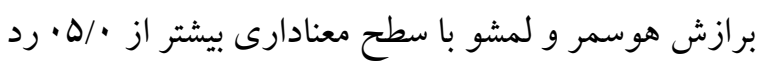
نشده و مىتوان گفت رسته بندى بيشخويى شده با مدل

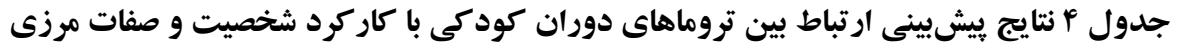

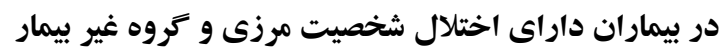

\begin{tabular}{|c|c|c|c|c|c|c|c|c|}
\hline \multicolumn{2}{|c|}{ ويشينى با ضريب •/ه9٪\% } & \multirow{2}{*}{ B } & \multirow[t]{2}{*}{ معنادارى } & \multirow[t]{2}{*}{ آماره والد } & \multirow[t]{2}{*}{$\mathbf{B}$} & \multirow[t]{2}{*}{ متغير ويشيين } & \multirow[t]{2}{*}{ كام } & \multirow{2}{*}{ متغير ملاكى } \\
\hline \multicolumn{2}{|c|}{ بالاترين مقدار بإينترين مقدار } & & & & & & & \\
\hline \multirow[t]{3}{*}{$r \cdot v / 1$} & $V Y V / I$ & $\Delta \cdot r / 1$ & $\cdots / \cdot$ & VTr/Tr & $r \cdot /$ & تجارب تروماتيكك & 1 & \multirow{5}{*}{ اختلال شخصيت } \\
\hline & & & & & & دوران كودكى & \multirow{4}{*}{$r$} & \\
\hline & & $\cdot \cdot r / \cdot$ & $\cdots / \cdot$ & $99 / \Delta \Delta$ & $-1 Y / 9$ & مقدار ثابت & & \\
\hline $.1 Y / 1$ & $. r 1 / 1$ & $. r / / 1$ & $\cdots / \cdot$ & $G F \Delta / 1 \Lambda$ & $\cdot r / \cdot$ & بد كار كردى شخصيت & & \\
\hline $1 \Delta \mathrm{V} / 1$ & $9 \cdot 1 / 1$ & r91/1 & $\cdots / \cdot$ & $1 \cdot 9 / 1 r$ & $r \cdot / \cdot$ & تجارب تروماتيكى & & \\
\hline
\end{tabular}

گروه اختلال شخصيت مرزى را از گرووه غير بالينى تفكيك نمايد.

\section{بحث}

هدف از اين ئزوهش بيش بينى كاركرد شخصيت و صفات مرضى در بيماران داراى اختلال شخصيت مرزى و گروه نرمال از طريق تروماهاى دوران كودكى بود. يافتهاى بُزوهش حاضر مويد فرض ما بود و نشان دادند كه افراد داراى اختلال شخصيت مرزى سطوح بالاترى از تروماهاى دوران كودكى را گزارش كردهاند. اين نتايج
آن جنان كه در جدول f م ملاحظه مىشود تجارب تروماتيكى دوران كودكى و بدكاركردى شخصيت به لحاظ آمارى بيشبينى كننده معنادارى براى احتمال به ابتلا به اختلال شخصيت مرزى هستند. تحليل رگرسيون لوجستيك دو جملهاى (VY/AY= قدرت تبيين بيشبينى بخت ( $\left.{ }^{2}\right) ؛$

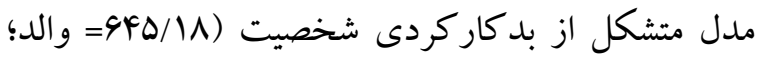

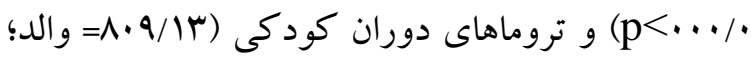

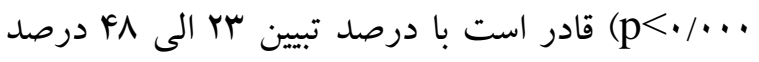


مواجه در "دوران حساس" باشد كه مغز انسان نسبت به جراحت و تروما آسيب بذيرتر است و منجر به سطوح

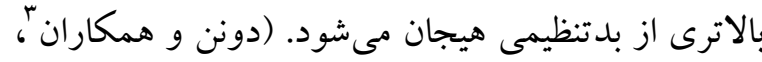

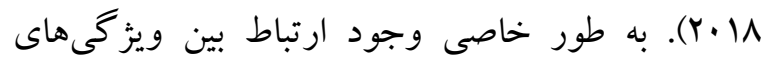
اختلال شخصيت مرزى و سوء استفاده جنسى دوران كودكى با اكثريت مقالات موجود در مورد اختلال شخصيت مرزى ساز گار است (روزنشتاين و همكاران،

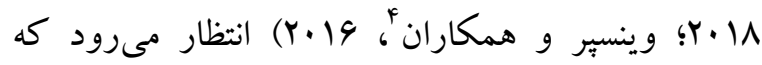
انواع سوء استفاده به عنوان مخربترين تروماهاى دوران كودكى اثرى دير با بر اختلال شخصيت مرزى داشته

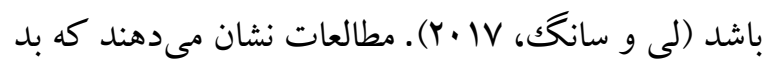
رفتارى عاطفى/ هيجانى (يعنى، حمله حاى كلامى به احساس خود، احساس ارزشمندى، بهزيستى يا ايمنى كودكs) بيشترين ارتباط را در ميان انواع بد رفتارى با افراد داراى اختلال شخصيت مرزى داشته باشد

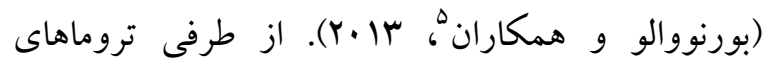
خاموشى هم وجود دارند كه مىتواند شامل ناتوانى مراقبت كنندهى اصلى كودكك در تعديل و تنظيم هيجان خود باشند و كودكان اين رفتارها را در اثر مشاهده و مدل سازى ياد بخيرند (برنووالووا و همكاران، سا •r). كه

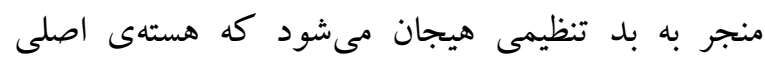
اختلال شخصيت مرزى مىباشد همجنين بعضى جنبه هاى

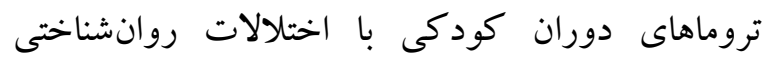

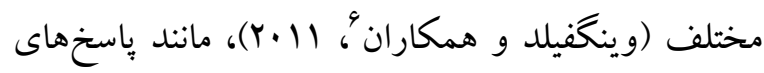
مرتبط با استرس (وينگفيلد و همكاران، سا.ب() در افراد داراى اختلال شخصيت مرزى مرتبط است (كاروالهى و همكاران، F| (Y). از طرفى در تبين رفتارهاى افراد داراى

3 - Dunn, et al.,

4- Winsper, et al.,

5 - Bornovalova, et al.

6. Wingenfeld et al
با يافته هاى روزنشتاين و همكاران (Y (Y) ، كاروالهى و همكاران (Y.|F) كه در بثزوهش ارتباط بين اختلال شخصيت مرزى و تروماهاى دوران كودكى به ويزه سوء استفاده و غفلت را تأييد كردند، و با يافتهاى عليلو و همكاران (Faf) كه در ئزوهشى نشان دادند، بدرفتارى دوره كودكى مىتواند اختلال شخصيت مرزى راني ييشبينى كند و با يافتهاى يورشهريار و همكاران (IMqV) كه آنها هم در يثزوهش ديخرى به اين نتيجه دست يافتند كه بين آزار هيجانى دوران كودكى و ويزًّى هاى اختلال شخصيت مرزى رابطه وجود دارد، همسو است. افراد داراى اختلال شخصيت مرزى در مقايسه با ساير افراد با ديخر اختلالات روانى و گرووه كنترل، سوء استفاده عاطفى، غفلت و نكهدارى ناكار آمد گزارش مى كنند كه

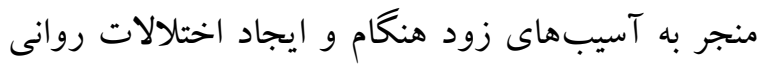

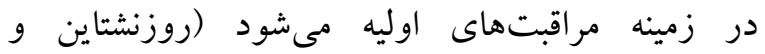

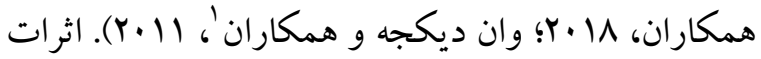
مضر سوء استفادهاى دوران كودكى بر سلامت روان مىتواند در طول عمر با تعديل و تأثير بر فرآيندهاى رشدى ادامه يابد و فرد را براى ابتلا به اختلالات روانى و

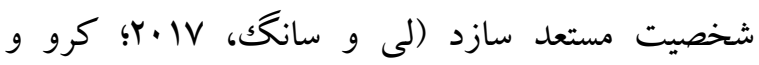

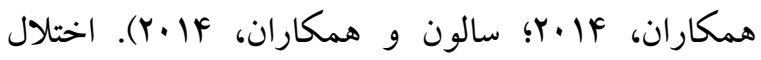
شخصيت مرزى از يك محيط زندگى نايايدار و غير قابل اطمينان دوران كودكى ايجاد مىشود و به طور خاص توسط سوء رفتار عاطفى مشخص مى شود ( روزنشتاين و

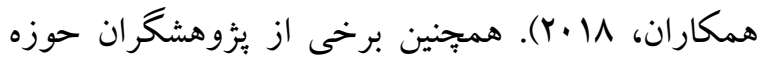
روانشناسى تحولى رابطه بين تروماى كودكى و علايم اختلال شخصيت مرزى در اين بيماران را نشان دادهاند

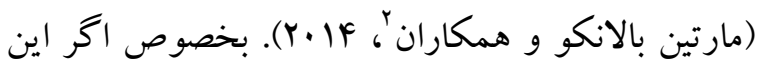

\footnotetext{
1- Van Dijke et al.

2- Martín-Blanco, et al.,
} 
در دوران كودكى خود تجربه مى كنند به شناخت بهترى

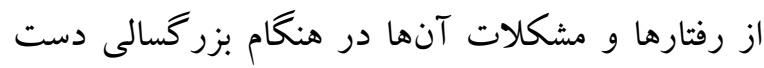
يافت و حتى از طريق بيشخيرى از مشكلات در دوران

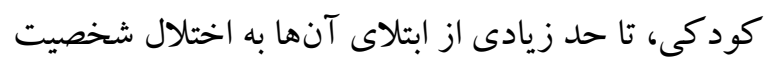

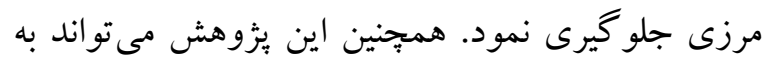
دركك بهترى از اختلال شخصيت مرزى طبق مدل جايكزين و ملاككهاى موجود در بنجمين ويرايش راهنماى تشخيصى و آمارى اختلالات روان يزشكى اشاره داشته باشد، زيرا يافته هاى بُوهش حاضر همجنان نشان داد كه بدكاركردى شخصيت يكك عامل اصلى ديخر تمايز گروه بالينى از غير بالينى مىباشد و به اين يافتهى مورد توجه رسيد كه افراد داراى اين اختلال شخصيت دجار بد كار كردى شخصيت در حيطههاى خود و بين فردى مىباشد. از طرفى يافتهاى حاضر مىتواند تلويحات كاربردى در حوزهى تشخيص افراد دارى اين اختلال شخصيت داشته باشد. اين يزوهش

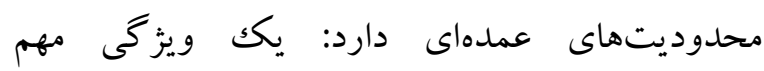
يثزوهشهاى تجربى، تعميميذيرى قابل اطمينان يافتها و انتخاب تصادفى آزمودنى هاست؛ اما در اين يثوهش جمع آورى دادهها از نمونههايى بود كه داوطلبانه حاضر به انجام همكارى شده بودند. همجنين اين مطالعه بر روى نمونهاى از دانشجويانى كه اعلام آمادكى كرده بودند و بيماران در دسترس مبتلا به اختلال شخصيت مرزى در شهر سنندج انجام گرفته است؛ يس از روشهاى دقيق نمونه يابى استفاده نشده است؛ بنابراين تعميم آن به كل جامعه بايد با احتياط صورت بكيرد. بنا به اقتضاى شرايط يخوهش شيوهى نمونه گيرى دو گرووه بالينى و غير بالينى

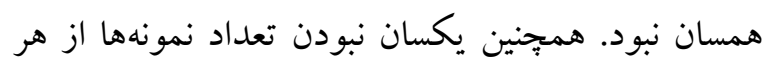
دو جنسيت؛ زيرا درصد شيوع اختلال شخصيت مرزى در
اختلال شخصيت مرزى مانند خودكشى و خود جرحى برخى از مقالات نشان دادهاند كه اين رفتارها ارتباط مستقيمى با سوء استفادهاى جنسى و جسمى تجربه شده

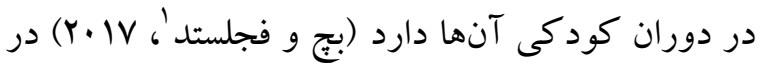
رابطه با صفات ينج كانه سياهه شخصيت براى ينجمين ويرايش راهنماى تشخيصى و آمارى اختلالات روان يزشكى مطالعات نشان دادهاند كه سوء استفاده هيجانى در كود كان با دل گسستگیى، مهار گستتگى، عاطفه منفى، روان بريش گرايى و نمره كل سياهه شخصيت براى بنجمين ويرايش راهنماى تشخيصى و آمارى اختلالات

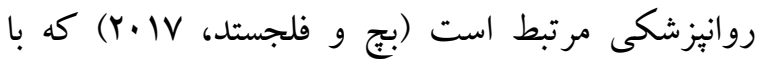
يافتهاى يثووشش حاضر ناهمسو مىباشد. اين ناهمسويى مى تواند به اين دليل باشد كه محدوديتهاى فرهنگ يُّى در برخى آيتمها مانند آيتمهاى مربوط به تروماهاى دوران كود كى خصوصاً سوء استفادههاى جنسى به دليل بنهان نخه داشتن شرايط خانوادگى از جانب آزمودنىها تأثير كذار بوده است. همجنين يكسان نبودن فرهنگ و و تعاريف متفاوتى از بىتوجهى و سوء استفاده هيجانى نيز در اين ناهمسويى مؤثر بوده است.

\section{نتيجه كيرى} نتايج به دست آمده يثوهش حاضر مى تواند راهخشاى پارهاى از ابهامات و بييجيدگیىهاى مربوط به اختلال

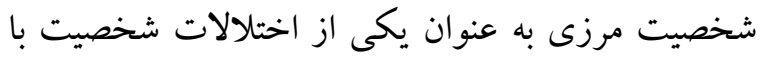
شيوع بالا هم در جمعيتهاى بالينى و هم جمعيتهاى غير بالينى باشد. جون در كروه بالينى افراد اكثراً در كودكى خود تجارب سوء استفاده و غفلت را داشتهاند، بس مىتوان از طريق آسيبها و مشكلاتى كه اين افراد

\footnotetext{
${ }^{1}$ - Bach \& Fjeldsted
} 
theory and methods. Joumal of Personality Assessment, 93(4), 332-346.

Bemstein D, Fink L. (1998). Childhood trauma questionnaire: A retrospective self-report: Manual. Psychological Corporation.

Bornovalova MA, Huibregtse BM, Hicks BM, Keyes M, McGue M, Iacono W. (2013). Tests of a direct effect of childhood abuse on adult borderline personality disorder traits: a longitudinal discordant twin design. Joumal of abnormal psychology, 122(1), 180.

Boyraz G, Lightsey Jr, Can A. (2013). The Turkish version of the Meaning in Life Questionnaire: assessing the measurement invariance across Turkish and American adult samples. Journal of personality assessment, 95(4), 423-431.

Brodsky BS, Mann JJ, Stanley B, Tin A, Oquendo M, Birmaher B, et al. (2008). Familial transmission of suicidal behavior: factors mediating the relationship between childhood abuse and offspring suicide attempts. J Clin Psychiatry:; 69(4): 584-96.

Carvalho Fernando S, Beblo T, Schlosser N, Terfehr K, Otte C, Lowe B,... \& Wingenfeld K. (2014). The impact of self-reported childhood trauma on emotion regulation in borderline personality disorder and major depression. Joumal of Trauma \& Dissociation, 15(4), 384-401.

Crow T, Cross D, Powers A, Bradley B. (2014). Emotion dysregulation as a mediator between childhood emotional abuse and cument depression in a low-income AfricanAmerican sample. Child abuse \& neglect, 38(10), 1590-1598.

Dunn EC, Nishimi K, Gomez SH, Powers A, Bradley B. (2018). Developmental timing of trauma exposure and emotion dysregulation in adulthood: Are there sensitive periods when trauma is most harmful?. Joumal of affective disorders, 227, 869-877.

Ebrahimi H, Dejkam M, Seghatoleslam T. (2014). Childhood Traumas and Suicide Attempt in adulthood. Iranian Journal of Psychiatry \& Clinical Psychology, 19(4). (In Persian)

Ensink K, Biberdzic M, Normandin L, Clarkin J. (2015). A developmental psychopathology

$$
\begin{aligned}
& \text { زنان و مردان متفاوت است. بيشنهاد مىشود اين بزوهش } \\
& \text { در استانهاى ديخر و با حجم نمونهاى بالينى بيشترى }
\end{aligned}
$$

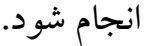

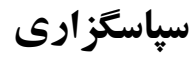

يثزوهش حاضر بركرفته از پايان نامه كارشناسى ارشد

دانشگاه كردستان و با كد

مصوب از كميته اخلاقى دانشگاه كردستان مىباشد. در

يايان از همكارى دانشجويان دانشگاه كردستان و مسئو لان

بيمارستان قدس سنندج و بيماران بسترى در اين بيمارستان

كه با شركت خود امكان انجام اين بثوهش را فراهم

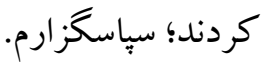

\section{References}

Akbari DA, Tamannaeifar S, Asghamejad FA. (2017). Autobiographical Memory and Interpersonal Problem Solving in Iranian Patients With Borderline Personality Disorder. Practice in Clinical Psychology, 5(2), 99-106. (In Persian)

American Psychiatric Association. (2013). Diagnostic and statistical manual of mental disorders (5th ed.). Washington, DC: American Psychiatric Association

Bach B, Fjeldsted R. (2017). The role of DSM-5 borderline personality symptomatology and traits in the link between childhood trauma and suicidal risk in psychiatric patients. Borderline personality disorder and emotion dysregulation, 4(1), 12.

Bach B, Sellbom M, Simonsen E. (2018). Personality inventory for DSM-5 (PID-5) in clinical versus nonclinical individuals: Generalizability of psychometric features. Assessment, 25(7), $815-825$.

Bender DS, Morey LC, Skodol AE. (2011). Toward a model for assessing level of personality functioning in DSM-5, part I: A review of 
and neurobiological model of borderline personality disorder in adolescence. Joumal of Infant, Child, and Adolescent Psychotherapy, 14(1), 46-69.

Esbec E, Echeburua E. (2015). The hybrid model for the classification of personality disorders in DSM-5: a critical analysis. Actas Esp Psiquiatr, 43(5), 177-86.

First MB, Gibbon M, Spitzer RL, Benjamin LS, Williams JB. (1997). Structured clinical interview for DSM-IV axis II personality disorders: SCID-II. American Psychiatric Pub.

Francis KJ, Wolfe DA. (2008). Cognitive and emotional differences between abusive and non-abusive fathers. Child abuse \& neglect, 32(12), 1127-1137.

Gabbard GO. (2010). Therapeutic action in the psychoanalytic psychotherapy of borderline personality disorder. In JF. Clarkin, P. Fonagy, \& GO. Gabbard (Eds.), Therapeutic action in the psychoanalytic psychotherapy of borderline personality disorder (pp. 1037). Arlington, VA: American Psychiatric Publishing.

Glaser D. (2002). Emotional abuse and neglect (psychological maltreatment): A conceptual framework. Child abuse \& neglect, 26(6-7), 697-714.

Gratz KL, Tull MT, Baruch DE, Bomovalova MA, Lejuez CW. (2008). Factors associated with co-occurring borderline personality disorder among inner-city substance users: The roles of childhood maltreatment, negative affect intensity/reactivity, and emotion dysregulation. Comprehensive psychiatry, 49(6), 603-615.

Hemmati A, Dezhkam M, Delavar A, Atef Vahid MK, Borjali A, Kamkari K. (2013). The Consistency between the Personality Psychopathology Five (PSY-5) Scale of the MMPI-2-RF and the Pathologic Traits of Altemative Model of Personality Disorder of DSM-5 (Section-III) in Iranian Population. Quarterly Clinical Psychology Studies. 3(12). 83-113. (In Persian)

Hemmati A, Morey LC, McCredie MN, Rezaei F, Nazari A, Rahmani F. (2020). Validation of the Persian Translation of the Level of Personality Functioning Scale-Self-Report (LPFS-SR): Comparison of College Students and Patients with Personality Disorders. Joumal of Psychopathology and Behavioral Assessment, 1-14. (In Persian)

Holm AL, Begat I, \& Severinsson E. (2009). Emotional pain: surviving mental health problems related to childhood experiences. Joumal of Psychiatric and mental health nursing, 16(7), 636-645.

Hopwood CJ, Thomas KM, Markon KE, Wright AG, Krueger RF. (2012). DSM-5 personality traits and DSM-IV personality disorders. Joumal of abnormal psychology, 121(2), 424.

Huang JJ, Yang YP, Wu J. (2010). Relationships of borderline personality disorder and childhood trauma. Chinese Joumal of Clinical Psychology, 18(6), 769-771.

Jellen LK, Mc Carroll JE, Thayer LE. (2001). Child emotional maltreatment: a 2-year study of US Army cases22. Child Abuse \& Neglect, 25(5), 623-639.

Krueger RF, Derringer J, Markon KE, Watson D, Skodol AE. (2012). Initial construction of a maladaptive personality trait model and inventory for DSM-5. Psychological medicine, 42(9), 1879-1890.

Lee MA, Song R. (2017). Childhood abuse, personality traits, and depressive symptoms in adulthood. Child abuse \& neglect, 65, 194-203.

Mahmoodaliloo M, Hashemi T, Beyrami M, Bakhshipoor A, SHarifi M. (2013). Investigating the Relationship between Childhood Abuse, Primary Loss and Separation, and Emotional Disorder with Borderline Personality Disorder. Joumal of Psychological Achievements, 4 (2). (In Persian)

Martin Blanco A, Soler J, Villalta L, Feliu Soler A, Elices M, Perez V, ... \& Pascual JC. (2014). Exploring the interaction between childhood maltreatment and temperamental traits on the severity of borderline personality disorder. Comprehensive psychiatry, 55(2), 311-318. 
Morey LC, Berghuis H, Bender DS, Verheul R, Krueger RF, Skodol AE. (2011). Toward a model for assessing level of personality functioning in DSM-5, Part II: Empirical articulation of a core dimension of personality pathology. Joumal of Personality Assessment, 93(4), 347-353.

Morey LC. (2017). Development and initial evaluation of a self-report form of the DSM-5 Level of Personality Functioning Scale. Psychological assessment, 29(10), 1302.

Mosquera D, Gonzalez A, Baldomir P, Vazquez I, Bello C, Eiriz AC. (2013).Personality disorders and intrafamilial early trauma. Poster session presented at the $\mathrm{V}$ Symposium on Borderline Personality Disorder.

Poorshahriyar H, Alizade H, Rajaiiniya K. (2018). The experience of childhood emotional harassment and the characteristics of borderline personality disorder in adulthood: The mediating role of attachment styles and emotional regulation. Iranian Joumal of Psychiatry and Clinical Psychology, 2(153). (In Persian)

Rezaei M. (2016). Developing cognitive-behavioral model for major depressive disorder. Comparing effectiveness of training based thismodel and emotional schema therapy (EST) on depression severity and rumination of patients whit major depressive disorder. Ph.D thesis,Faculty of Literature and Humanities, Lorestan university. (In Persian)

Roemmele M, Messman Moore TL. (2011). Child abuse, early maladaptive schemas, and risky sexual behavior in college women. Joumal of child sexual abuse, 20(3), 264-283.

Rosenstein L, Ellison WD, Walsh E, Chelminski I, Dalrymple K, Zimmerman M. (2018). The Role of Emotion Regulation Difficulties in the Connection Between Childhood Emotional Abuse and Borderline Personality Features.

Roy A. (2011). Combination of family history of suicidal behavior and childhood trauma may represent correlate of increased suicide risk. Journal of Affective Disorders, 130(1), 205208.
Salwen JK, Hymowitz GF, Vivian D, O'Leary KD. (2014). Childhood abuse, adult interpersonal abuse, and depression in individuals with extreme obesity. Child abuse \& neglect, 38(3), 425-433.

Sarabi P, Sadeghi Kh. (2018). Evaluation of the agreement between Milon-3 multiaxial clinical test and personality questionnaire (SCID-II) in diagnosing personality disorders. Scientific Journal of Psychological Development, 7 (10), 131-146. (In Persian)

Trickett PK, Mennen FE, Kim K, Sang J. (2009). Emotional abuse in a sample of multiply maltreated, urban young adolescents: Issues of definition and identification. Child abuse \& neglect, 33(1), 27-35.

Van Dijke A, Ford J, Van Der Hart O, Van Son M, Van Der Heijden PGM, Buhring M. (2011). Childhood traumatization by primary caretaker and affect dysregulation in patients with borderline personality disorder and/or somatoform disorder. European Journal Of Psychotraumatology, 2, 5628.

Van Dijke A, Hopman JA, Ford JD. (2018). Affect dysregulation, psychoform dissociation, and adult relational fears mediate the relationship between childhood trauma and complex posttraumatic stress disorder independent of the symptoms of borderline personality disorder. European Joumal of Psychotraumatology, 9(1), 1400878.

Wingenfeld K, Kuffel A, Uhlmann C, Terfehr K, Schreiner J, Kuehl LK,... \& Spitzer C. (2013). Effects of noradrenergic stimulation on memory in patients with major depressive disorder. Stress, 16(2), 191-201.

Wingenfeld K, Schaffrath C, Rullkoetter N, Mensebach C, Schlosser N, Beblo T,... \& Meyer B. (2011). Associations of childhood trauma, trauma in adulthood and previous-year stress with psychopathology in patients with major depression and borderline personality disorder. Child Abuse \& Neglect: The International Joumal, 35(8), 647-654.

Wingenfeld K, Spitzer C, Mensebach C, Grabe HJ, Hill A, Gast U, ... \& Driessen M. (2010). Die 
deutsche version des childhood trauma questionnaire (CTQ): erste befunde $\mathrm{zu}$ den psychometrischen Kennwerten. PPmPPsychotherapie. Psychosomatik. Medizinische Psychologie, 60(11), 442-450.

Winsper C, Lereya ST, Marwaha S, Thompson A, Eyden J, Singh SP. (2016). The aetiological and psychopathological validity of borderline personality disorder in youth: A systematic review and meta-analysis. Clinical psychology review, 44, 13-24.

Wright AG, Pincus AL, Hopwood CJ, Thomas KM, Markon KE, Knueger RF. (2012). An interpersonal analysis of pathological personality traits in DSM-5. Assessment, 19(3), 263-275.

Zanarini MC, Frankenburg FR. (1994). Emotional hypochondriasis, hyperbole, and the borderline patient. The Joumal of psychotherapy practice and research, 3(1), 25.

Zanarini MC, Frankenburg FR. (1997). Pathways to the development of borderline personality disorder. Joumal of personality disorders, 11(1), 93-104.

Zanarini MC, Yong L, Frankenburg FR, Hennen J, Reich DB, Marino MF, Vujanovic AA. (2002). Severity of reported childhood sexual abuse and its relationship to severity of borderline psychopathology and psychosocial impairment among borderline inpatients. The Journal of nervous and mental disease, 190(6), 381-387.

Zanarini MC. (1993). Borderline personality disorder as an impulse spectrum disorder. Borderline personality disorder. Etiology and treatment, 67-86. 